\title{
Money Demand In South Africa Revisited: A Detailed Analysis Of Different Models
}

Ferdinand Niyimbanira, Vaal University of Technology, South Africa

\begin{abstract}
Many macroeconomists acknowledge the importance of behavior in a money demand relationship when formulating an efficient monetary policy. Many efforts have been made to estimate the money demand in function using many different specifications. This paper discusses South African empirical literature review of money demand. It revealed that different methods have been used to analyze the demand for money in South Africa, such as the linear function approach, the partial stock adjustment model, and the buffer stock disequilibrium money model. This study also discovered that few studies are done using co-integration and error correction methods and not all of these studies show that the money demand function in South Africa is stable. Implication for theory and practice, as well as area of future research, are also discussed in the study.
\end{abstract}

Keywords: Model; Money Demand; South Africa

\section{INTRODUCTION}

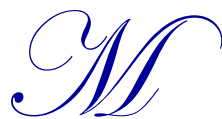

uch theoretical and empirical research on the demand for money has been carried out in South Africa over the past four decades. These studies evaluated money demand using different approaches. This paper looked at four different approaches. The first approach dealt with money demand in South Africa using the Co-integration and Error Correction Models which have become increasingly popular in the literature. The second was the partial stock adjustment model, which is an extremely popular method from the 1970s (Sriram, 2001). Generally, though, as shown by many studies, for example Cooley and LeRoy (1981), Goodfriend (1985), Hendry (1985), Hendry and Mizon (1978) and many others, this method of partial stock adjustment suffered from specification problems and highly restrictive dynamics. The third is the linear function approach. The fourth approach is the buffer-stock model, which was based on the theory of the precautionary demand for money, as described in Cuthbertson and Taylor (1987) and Milbourne (1988).

According to Shin (1994), "it is thought to be important, for both economic and statistical reasons, to be able to determine whether there is a stable long-run relationship between multiple economic series, even though each series is considered to be I(1) process." The concept of stable, long-run equilibrium is demonstrated by Granger (1986) as "the statistical equivalence of co-integration." Therefore, when co-integration holds, and if there is any shock that causes disequilibrium, there exists a short-term dynamic adjustment process, such as the Error Correction Mechanism, that pushes the system back toward the long-run equilibrium (Sriram, 2001). The existence of a dynamic error-correction form relating to the variables in question is implied by co-integration (Engle and Granger, 1987).

\section{CO-INTEGRATION AND ERROR CORRECTION MODELLING}

Hurn and Muscatelli (1992) agreed that some studies, such as Courakis' (1984), who used the autoregressive distributed lag approach, on the one hand, and Whittaker (1985) and Tavlas (1989), who used buffer stock approach, on the other hand, to estimate the money demand function in South Africa, discovered that the function was stable over time. Hurn and Muscatelli pointed out that these studies did not manage to estimate the long-run relationship between money demand and its determinants. With the data period from 1965(I) to 1990(IV), they used the co-integration approach to examine this relationship and the nature of the long-run elasticities of the model. 
Hurn and Muscatelli (1992, p.158) gave two main aims of their study to: 1) outline how recent developments in the theory of co-integration enable the estimation of the long-run responses of a linear model within a maximum likelihood framework and 2) investigate some of the long-run properties of the demand for the broad South African monetary aggregate M3. The choice of broad M3 was made because it was considered the highest broad money balance in South African monetary policy targets. Therefore, it was chosen to be the dependent variable. The explanatory variables chosen to regress with M3 were real income, which is measured as GDP at constant prices, the interest rate being the average of the commercial bank retail deposit rate (DR), and the interest rate on three year government stock $(\mathrm{R})$. Before proceeding to the estimation of the long-run demand function for M3, Hurn and Muscatelli checked if all time series were the same order of co-integration, as required by cointegration methodology theory. Hence, the following equation is estimated:

$$
M 3_{t}=\beta_{0}+\beta_{1}(Y-P)_{t}+\beta_{2} P_{t}+\beta_{3} D R_{t}-\beta_{4} R_{t}+\mu_{t}
$$

where $(Y-P)$ is real income, $P$ stands for prices, DR is own interest rate, and $\mathrm{R}$ is the alternative interest rate. All determinants were found positively related to real M3, except the alternative interest rate which was negatively related. Those results meet the expectations of economic theory; therefore, they suggest that there was a long-run relationship between $\mathrm{M} 3$ and its determinants.

Then Hurn and Muscatelli tested for unit price and income elasticities of demand. In terms of income, unitary elasticity was rejected; it could not be imposed on the long-run demand function. Further study of South African literature, using GDP as the scale variable, was suggested. The wealth variable would be a better choice in this case, but the data are difficult to measure. Unity price elasticity was also rejected. The last step is to test the null hypothesis of equality of the two interest rate elasticities. The outcome shows that they have equal magnitude, but opposite signs, and the hypothesis was accepted, indicating that it would be appropriate to use interest rate differentials rather than the levels. The interest elasticities were statistically significant and an important point to be noted because interest rates were found to be insignificant in previous studies. Hurn and Muscatelli concluded that the long-run relationship between real M3, income, prices and interest rates in South Africa, using the co-integration analysis the function, appears to be well behaved. The coefficients were found to be statistically significant with the correct signs. Hence, a long-run relationship between real M3 and its explanatory variables does exist, according to them.

Moll (2000) analysed the demand for money using a co-integration approach, with real variables rather than nominal money and income. The following equation was estimated:

$$
(m-p)=\beta_{0}+\beta_{1}(y-p)+\beta_{2} r_{M 3}+\beta_{3} r_{10}+\beta_{4} \Delta p+\varepsilon_{t}
$$

where $m$ is M3, $\mathrm{p}$ is the price level, $\mathrm{y}$ is GDP, $\mathrm{r}_{\mathrm{M} 3}$ and $\mathrm{r}_{10}$ are interest rates, and $\Delta \mathrm{p}$ is the inflation rate. The $\beta$ 's are the coefficients and $\varepsilon$ the error term. According to the quantity theory of money by Friedman (1956), the coefficient of income was expected to be equal to one or it was expected to be 0.5 with the transaction's demand theory of money (Baumol, 1952). The expectations of other coefficients were that $\beta_{2}>0$ and $\beta_{3}, \beta_{4}<0$.

In terms of real income, the results showed that the elasticity is close to unity (their estimate was 1.11), which was a standard finding and similar to the one of Tavlas (1989) and others. Both interest semi-elasticities had the expected signs, while the inflation rate tended to reduce real money demand. The interest rate variables were not directly comparable with those estimated by Tavlas because Moll's interest rate variables were in logarithmic terms. Then Moll compared many different types of co-integrating vectors, such as using the Johansen-Juselius trace, a Hendry/PcGive unit root, and the popular two-step approach of Engle and Granger. The results showed that all these tests gave the same signs. The coefficients on lagged real income were very close with these methods. Hence, these approaches corroborate each other. Moll realizes that the Engle-Granger test is not valid in the study and this led to the three unit root test's failure to reject the null hypothesis of non-co-integration.

Moll concluded that the money demand function of the period of study had stable parameters and could be predicted better using this model rather than other alternatives. Moll discovered that real M3 surged in the period 
1993-1998, growing by 39 percent when real income grew by 11 percent. Therefore, there was no structural change and this could be explained by the decline of inflation.

Nell (2003) analyses the stability of M3 money demand and monetary growth targets in South Africa using the co-integration approach. The long-run money demand model was:

$m 3_{t}=\beta_{0}+\beta_{1} y_{t}+\beta_{2} p_{t}^{c}+\beta_{3}(R M-R O)_{t}+\mu_{t}$.

where $\mathrm{m} 3$ stands for the demand for nominal M3 money balances, $y$ is real income (GDP), $\mathrm{p}^{\mathrm{c}}$ is the price level (CPI), RM represents the ten-year government bond yield, and RO the long-term own interest rate represented by the fixed deposit rate of twelve months. The results of the Augmented Dickey-Fuller (ADP) unit root tests for Nell indicated that the interest rate differential (RM-RO) is $\mathrm{I}(0)$ and would therefore co-integrate with a unit coefficient while all other variables (income, price level) appeared to be I(1). Based on Engle-Granger's procedure, Nell estimated the long-run relationship, which is found to be I (1), with the following equation:

$m 3_{t}=\beta_{0}+\beta_{1} y_{t}+\beta_{2} p_{t}^{c}+\mu_{t}$

The results indicated that $\mathrm{m} 3, \mathrm{y}$ and $\mathrm{p}^{\mathrm{c}}$ were co-integrated at the five percent significance level. Therefore, there was a long-run relationship between $\mathrm{m} 3$, income, and the price level. If real money was $\mathrm{I}(1)$ and inflation rate $\mathrm{I}(0)$, the long-run relationship between real money and inflation may be spurious (Nell, 2003). The co-integration approach appeared to be useful as a first indicator because it helps to avoid some complicated problems that may occur with other methods when analyzing the demand for money. Some studies, such as Inder (1993), showed that the omission of dynamics may be adjusted for using error correction modeling. as follows:

Kennedy (1998) and Charemza and Deadman (1993) gave a format of the error correction model estimation

$\Delta y_{t}=\beta_{0}+\beta_{1} \Delta x_{t}+\beta_{2} \Delta y_{t-1}+\beta_{3}\left(y_{t-1}-x_{t-1}\right)+\varepsilon_{t}$.

Nell (2003) applied this format of the error correction model with consideration of the lags of the dependent variable $(\Delta \mathrm{m} 3)$ :

$\Delta m 3=-8065-0.34 \Delta m 3_{t-2}+1.27 \Delta y+0.76 \Delta p-0.006 \Delta(R M-R O)-0.01 \Delta(R M-R O)_{t-1}+0.06 D_{70 S}-0.59 e c m_{t-1}$

The Error Correction coefficient of -0.59 gives approximately one year for the money market in South Africa to readjust back to the equilibrium. Likewise, with South African data, Naudè (1992) estimates an Error Correction Model to estimate the long-run equilibrium relationship between dependent and independent variables for desired money holdings with the following equation:

$m^{*}=k+\Phi_{0} p+\Phi_{1} y+\Phi_{2} r+\Phi_{3} \Delta p$

where $\mathrm{m}^{*}$ is the desired level of money holdings, $\mathrm{p}$ stands for price level (CPI), $\mathrm{y}$ is real disposable income, $\mathrm{r}$ for the three-month Treasury Bill rate, and $\Delta \mathrm{p}$ the inflation rate, as measured by the growth rate in the consumer price index. All variables were in logarithmic terms. After manipulating the partial adjustment model and going through the analysis of a loss function serving as a rationale for estimating money demand within the Partial Adjustment model, Naudè obtained the following Error Correction Model:

$$
\begin{aligned}
& \Delta m^{*}=\delta_{0}+\left(\phi_{1}+\phi_{7}\right) \Delta p_{t}+\left(\phi_{2}+\phi_{6}\right) \Delta y_{t}+\left(\phi_{3}+\phi_{7}\right) \Delta r_{t}+\left(\phi_{4}+\phi_{9}\right) \Delta^{2} p_{t}+\left(\phi_{5}-1\right)\left[m_{t-1}-p_{t-1}-y_{t-1}\right] \\
& +\phi_{3} r_{t-1}+\phi_{4} \Delta p_{t-1}
\end{aligned}
$$


where $\left(\phi_{5}-1\right)\left[m_{t-1}-p_{t-1}-y_{t-1}\right]$ is the error correction term which indicates the proportion of the disequilibrium between nominal income and money that is corrected from the one period to the next (Boswijk, 1990, p.101). Naudè's results showed two important features when compared to previous studies. First, the short-run income elasticity was high and second, the short-run elasticity of inflation was large. These two features of the Error Correction Model in South Africa might be caused by the instability of the money demand function, as well as political and social instability during the period. Naudè compares the results obtained from the ECM and those found when using the partial adjustment model by Contogiannis and Shahi (1982) and Courakis (1984). With the ECM, the problem of serial correlation was solved while it was rejected by partial adjustment methods. In addition, with the ECM, the hypothesis of unitary long-run income and price elasticities were not rejected.

Similarly, Tlelima and Turner (2004, p.25-36) estimated the demand for money in the South African economy during the period 1971: I to 2002: III using the Error Correction Model. GDP and consumption were used as the alternative scale variables. The following equations represented the money demand function with GDP and consumptions scale variables, respectively:

$$
\begin{aligned}
& \Delta m_{t}=\varphi_{1} \Delta y_{t}+\varphi_{2}\left(i_{t-1}-i_{t-4}\right)+\varphi_{3}\left(\pi_{t-1}-\pi_{t-4}\right)-\varphi_{4} \Delta \pi_{t}-\varphi_{5}\left(m_{t-1}-y_{t-1}+i_{t-1}+\pi_{t-1}\right)+\varepsilon_{t} \\
& \Delta m_{t}=\varphi_{1}\left(i_{t-1}-i_{t-4}\right)+\varphi_{2}\left(\pi_{t-1}-\pi_{t-4}\right)-\varphi_{3} \Delta \pi_{t}-\varphi_{4}\left(m_{t-1}-c_{t-1}+i_{t-1}+\pi_{t-1}\right)+\varepsilon_{t}
\end{aligned}
$$

The coefficients of determination of both equations were very close -0.31 for 4.9 and 0.29 for equation 10 . Standard errors of these equations are the same (0.02) and Durbin-Watson values were also close - 2.04 and 2.06. Even though the results showed that there was no indication of significant misspecification, equation 9 appeared to be better due to its economic interpretation. A direct estimation of equation 5 probably would not be the best way forward because of the fact that in 5, the variables have, by assumption, different orders of integration. Both $\Delta \mathrm{y}_{\mathrm{t}}$ and $\Delta \mathrm{x}_{\mathrm{t}}$ may be $\mathrm{I}(0)$, while $\mathrm{x}_{\mathrm{t}-1}$ and $\mathrm{y}_{\mathrm{t}-1}$ are $\mathrm{I}(1)$ (Charemza and Deadman, 1993).

\section{THE PARTIAL STOCK ADJUSTMENT MODEL}

According to Handa (2000, p.161), lags often occur in the adjustment of a variable to its desired long-run value and one reason for such a lag can be the short-run cost of making changes to any variable. The following model of Maxwell's used similar variables to other studies here and estimated that

$$
\ln M_{t}=\alpha_{0}+\alpha_{1} \ln M_{t-1}+\alpha_{2} \ln r+\alpha_{3} \ln A_{t}
$$

where $M_{t}$ represents the observed real money stock at time $t, r$ was the interest rate, and A the appropriate wealth constraint. The results from this regression substantially improve earlier work. The $t$-ratios showed that the coefficients were statistically significant. Durbin-Watson (DW) tests showed that there was no autocorrelation and also shows that there was no misspecification at the 1 percent significance level, unlike previous studies. Chow tests indicated that the demand function was not stable. When running the regression in separate sub-periods, the function performs differently (Maxwell, 1971, p.18), but not convincingly enough to conclude that function 11 was stable.

Maxwell's work was surprisingly modern then and used the partial adjustment model (pre- and post-war periods), and he indicated that the results were different. For the pre-war period, the results were good for narrow (M1) and broad (M2) money because the standard error of estimation was small; and even though the DW was high, the coefficients of the variables were significant and met the conditions of money demand theory with expected signs. For the post-war period, the results showed signs of autocorrelation and the M1 coefficients had unexpected signs and were insignificant. Due to these differences, Maxwell concluded that the money demand function was not stable in the long-run. 
Stadler (1981) also used the Partial Adjustment Model and considers $\mathbf{M}^{*}$ as money balances individuals would like to hold and its demand or quantity will change over time as income, interest rates and other determinants change. However, he found it also reasonable to assume that the quantity of money demanded was not instantaneously adjusted in response to the said determinants. The difference between desired and actual money balance brings into existence a fraction $(g)$ of desired change for a given time period. The following is the Partial Adjustment Model used by Stadler:

$$
M_{t}-M_{t-1}=g\left(M_{t}^{*}-M_{t-1}\right) \text {. }
$$

where $0<\mathrm{g}<1$. Thus, $M$ was moved to its desired level when compared to the immediate past, but only a fraction of this adjustment was achieved. If desired balances $M^{*}$ were determined by a decrease of expected income $(\gamma)$ and price $(\mathrm{p})$, then the following equation exists:

$$
M_{t}^{*}=b_{0}+b_{1} \gamma_{t}+b_{2} p_{t}+\mu_{t} \text {. }
$$

The combination of the adjustment with the determinants in (13) gives:

$$
M_{t}=g b_{0}+g b_{1} \gamma+g b_{2} p_{t}+(1-g) M_{t-1}+g \mu_{t} .
$$

The results Stadler obtained indicate that in one quarter, the coefficient of adjustment gives 45 and 30 percent as the adjustment for $\mathrm{M}_{1}$ and $\mathrm{M}_{2}$, respectively. Stadler considered that expected income is directly observable and proposes the following hypothesis for income expectations:

$$
\gamma^{*}-\gamma_{t-1}^{*}=k\left(\gamma_{t}-\gamma_{t-1}^{*}\right)
$$

where $0<\mathrm{k}<1$ and $\gamma^{*}$ represents expected income. With this adjustment, there was high multicollinearity between the variables.

As does Stadler, Contogiannis and Shahi (1982, p.26-34) also included price levels in the estimated model instead of an interest rate. As an extension of Stadler's work, the examination of the demand for money first used price expectations alone, then price expectations and a partial demand adjustment factor, and lastly, both together. Adaptive expectations' mechanisms were constructed for other explanatory variables, such as income. The data covered the period 1965-1980. With an adaptive expectations process, the following equation was the adjustment capturing price expectations:

$$
P_{t}^{*}-P_{t-1}^{*}=\delta\left(P_{t}-P_{t-1}^{*}\right) \text {, }
$$

where $\delta$ is the coefficient of price expectations, standing for the fraction of the difference between actual and the previous (lag) price and $0 \leq \delta \leq 1$. It is assumed that individuals adjust their actual money balances to desired levels by a fixed proportion $\gamma$, which is the coefficient of adjustment. The following was for the price expectations plus a partial adjustment model:

$$
M_{t}-M_{t-1}=\gamma\left(M_{t}^{*}-M_{t-1}\right),
$$

where $0 \leq \gamma \leq 1$ and actual money balances adjust to desired levels. Using the function

$$
M_{t}^{*}=a+b y_{t}+c P_{t}^{*}+\mu_{t},
$$


with $y_{t}$ being real income, Contogiannis and Shahi develop their 'Model B':

$$
M_{t}=a \gamma \delta+b \gamma y_{t}-b \gamma(1-\delta) y_{t-1}+c \gamma \delta P_{t}(2-\gamma-\delta) M_{t-1}-(1-\gamma)(1-\delta) M_{t-2}+\mu_{t}
$$

which was estimated using a non-linear estimation method. This method was also used when combining adaptive expectations and Partial Adjustment Methods. Therefore, one should take in consideration the inclusion of inflation in money demand function. Contogiannis and Shahi (1982, p.29) gave reasons for supporting the inclusion of the price level in the money demand function by stating that “... in line with evidence found in other countries, people seem to treat money in the same way as luxury goods - as something of which they like to hold proportionately more when their real incomes are higher. The results also indicate that the expected change in price is a significant variable in the demand for money function." The expected price level was highly significant, with an elasticity of negative 0.5. Real income has the expected sign, with elasticity greater than one. According to other studies on South Africa (Heller, Maxwell; Stadler; Contogiannis and Shahi), one may conclude that, contrary to parts of traditional theory, money demand is determined by income and the price level, rather, as the interest rate effect is weak.

In his work, Courakis (1984, p.1-41) acknowledged the importance of expectations in determining the demand for money and the possibility of how the desired money stock adjusts to changes in the actual money stock with a time lag, as shown by Stadler (1981) and Contogiannis and Shahi (1982). Courakis (1984) pointed, out after deriving all relationship $a b$ initio, that there were conceptual problems with the theoretical equations of Stadler and Contogiannis and Shahi. Courakis avoided these problems for the period of 1960-1980, using the following logarithmic money demand function found in the famous paper of Friedman (1959, p.111-139):

$$
M_{t}=\alpha_{0}+\alpha_{1} \bar{Y}_{t}+\alpha_{2} \bar{P}_{t},
$$

where $M_{t}$ is nominal money balances, $\bar{Y}$ is permanent real income, and $\bar{P}$ the permanent price level. Equation 20 is used to obtain

$$
M_{t}=\lambda \delta \alpha_{0}+\lambda \delta \alpha_{1} Y_{t}-\lambda(1-\delta) \alpha_{1} Y_{t-1}+\delta \alpha_{2} P_{t}-\lambda(1-\delta) \alpha_{2} P_{t-1}+(2-\lambda-\delta) M_{t-1}-(1-\lambda)(1-\delta) M_{t-2}
$$

All variables in (21) are in logarithmic terms. This is the equation Courakis considered most useful for his study. Using the Chi-squared test, he found that the hypothesis of unitary income expectations and equal expectation coefficients for real income and the price level were statistically insignificant. The estimation of equation (21) shows a significant improvement, but it is not sufficient as it does not include an interest rate variable. This is the reason why Courakis decided to adjust 21; seeking a more general specification of the money demand function to include interest rates and expected inflation as additional determinants to obtain the following log-linear function:

$$
M_{t}=\alpha_{0}+\alpha_{1} \bar{Y}_{t}+\alpha_{2} \bar{P}_{t}+\alpha_{3} \bar{R}_{t}+\alpha_{4} \bar{X}_{t}
$$

where $\bar{X}_{t}=\bar{P}_{t}-P_{t-1}^{-}$and $\bar{R}$ is the permanent or expected interest rate, such that $\bar{R}_{t}=\mu R_{t}+(1-\mu) R_{t-1}^{*}$.

Courakis's study unexpectedly gave the elasticities of demand with respect to the permanent price level. With respect to permanent income, elasticities of demand of M1 and M2 were more than one which indicates misspecification. Therefore, there was no homogeneity between income and price. This leads to a rejection of Friedman's (1957) theory as he found that the income elasticity is more than one. Courakis disagrees with the use of a price level by Contogiannis and Shahi (1982). Courakis $(1985, \mathrm{p} .12)$ felt that "the expected price level cannot, by itself, serve as a proxy for the expected rate of change in the price level". The inclusion of both the interest rate and the expected inflation rate in the money demand function gave new results. The interest rate did not add the analysis, but the price expectations variable was found to be statistically significant. Courakis proceeded to the adjustment 
mechanism of actual to desired money balances using the following equation:

$$
M_{t}=\gamma M_{t}^{*}+(1-\gamma) m_{t-1}+\phi\left[\left(M_{t}^{*}-M_{t-1}\right)-\left(M_{t-1}^{*}-M_{t-2}\right)\right]
$$

where $M^{*}$ is the desired stock of money balances. This adjustment is nominal rather than real.

Although the expected rate of inflation remained an important determinant of money demand with the expected sign (negative), Courakis $(1984$, p.17) did not find any role attached to opportunity cost in terms of financial assets which may lead to a misspecification in the model. It is confirmed that "irrespective of the nature of the expectation formation processes for $\bar{Y}, \bar{P}$ and $\bar{R}$ and of serial correlation pattern, the Hypothesis that the demand for narrow money does not depend on opportunity costs in terms of financial assets does not, for any of the 27 variants of the envelope relationship, carry a probability of acceptance of even 1, 0 percent (Courakis, 1984, p.31)." Courakis did not consider the characteristics of the error terms. The estimation was based on an assumption of the white noise disturbance term being attached to the reduced form he derived. Courakis (1984, p.18) realized that with the consideration of white noise disturbance terms, "the possibility that the true structural model implies a reduced form that exhibits auto-correlated disturbances cannot be precluded". The results showed the interest rate to be statistically significant. Furthermore, it remained statistically significant even when lagged values of the dependent variable are of a higher order than two. For income, the elasticity of demand for narrow money is found to be less than, or equal to, unity, which is different from what is predicted by theory (Friedman, 1956, p.58). For the price level, the elasticity was also less than one. Moreover, as theory suggests, opportunity costs, in terms of a return on alternative financial assets, are the least significant determinant of the demand for narrow money. In the conclusion of his study, Courakis (1984, p.37) confirmed that "the overall best equations trace the movement of M1 very closely and exhibit no structural breaks, notwithstanding the direct intervention policies of the authorities and the fluctuations in economic activity that characterize experience over the period under review." The long-run demand for money in South Africa is stable during the period 1965-1980 according to the above research.

In his comments about the demand for money in South Africa, Whittaker (1985, p.184-196) considered many shortcomings of the previous work of Stadler, Contogiannis and Shahi and Courakis. He argued that Courakis' study does not present a clear picture or define the parameters of the South African money demand function. He noted that Courakis did not manage to convincingly verify or reject any of the theoretical relationships connected with the money demand function. Whittaker was specific when he criticized the usage of the Chi-squared test by Courakis and suggested that using the $\mathrm{F}$ test may lead to lower levels of confidence in the rejection of constrained forms of the estimated equations. For example, the critical value of the F-distribution shows that the Hypothesis could not be rejected at 1 percent significance level but it could be with the Chi-Squared test $\left(\chi^{2}\right)$.

Whittaker proceeded by accepting that the Koyck terms are statistically insignificant and then introduced the following equation to test the model with different data series and time periods:

$$
M_{t}=a_{0}+\sum_{\omega=0}^{6} a_{y \omega} Y_{T-\omega}+\sum_{v=0}^{6} a_{p v} P_{t-v}+\sum_{\sigma=0}^{6} a_{r \sigma} R_{t-\sigma}+\sum_{j=1}^{7} a_{m j} M_{t-j}+\mu_{t}
$$

where the variables are defined in the usual way.

Another reason for re-estimating the equation was to test the robustness of Courakis' money demand equation under different circumstances. The results showed that the parameter values were different for each data set and change markedly. Their standard deviations were large, unlike Courakis' results, and they appeared to be unstable. By using the Chow test for stability, Whittaker discovered that the estimated parameters are not appropriate for the entire set of observations. The hypothesis of parameter constancy was therefore rejected. Whittaker believed that Gross Domestic Product was probably not too different from Gross Domestic Expenditure (GDE) and that it was more appropriate when examining the demand for narrow money. GDP is measured in ways that makes it prone to error. Instead of measuring the opportunity cost of holding money, using the Treasury-Bill (TB) rate, Whittaker offered that the rate for three-month Bankers' Acceptances (BA) is better because "most of the 
existing stock of TB's has been in the hands of the Reserve Bank or National Finance Corporation as a result of rediscounts and the participation by these institutions in the tender system" (Whittaker, 1985, p.190-191). The BA rate is an appropriate measure of the market cost of short-term credit. However, when the BA rate is used instead of the TB rate, the results showed that the coefficient was positive and close to unity while it was expected to be negative. It was also statistically insignificant. Whittaker realized that there was little point in discussing other parameter values because they display large variances and instability. Based on the sensitivity of the estimated parameters to the model structure, Whittaker was of the opinion that the time period of study, the data series, and the results showed the demand for narrow money, even over that period covered by Courakis, was unstable.

\section{THE LINEAR FUNCTION APPROACH}

Apart from the velocity of circulation studied by Lachmann (1956) and De Kock (1956), the study of the demand for money in South Africa begins with Heller (1966). In his estimation of money demand, he considered money as coins, notes, and most deposits. This combination is the dependent variable, while the explanatory variables were current income represented by GNP, an interest rate (which is measured by a fixed 12-month rate paid by commercial banks) and union Treasury-Bill rates. A third determinant was the general price level explained by the wealth deflator. Heller considered wealth as one of the determinants of money demand. The following is the model in Heller's study:

$$
M_{t}=\alpha_{0}+\alpha_{1} G N P_{t}-\alpha_{2} W_{t}+\alpha_{3} P_{t}-\alpha_{4} R_{t}+\mu_{t} \text {. }
$$

He added $M$ as nominal money demand, GNP is current nominal income, $\mathrm{W}$ is wealth, and $\mathrm{R}$ is the interest rate variable (Treasury-Bill rate and 12-month fixed deposit rate). $\mathrm{P}$ is the price level and $\mu$ the error term. One may ask the following questions: 1) How is wealth defined in this case? 2) How does it differ from income and why are both included in one model? To partly answer these questions, Heller (1966, p.336) estimates equation (25) three times by excluding the wealth variable and GNP each time. From this, it was discovered that the $\alpha_{1}$ coefficient changed its value slightly while the (wealth) $\alpha_{2}$ coefficient was unstable. Therefore, in this case, income was the relevant determinant of $M_{t}$ compared to wealth.

Heller (1966, p.337) found that "the inclusion of the price level among the independent variables increases the explanatory power of the equation significantly". This is expected if a nominal measure of money is used. Among the two different interest rates used, the union Treasury-Bill rate is found to be insignificant and the interest rate on 12-month fixed deposits was the 'best' for the model. Thus, the model becomes:

$$
M_{t}=\alpha_{0}+\alpha_{1} G N P_{t}+\alpha_{3} P_{t}-\alpha_{3} R_{t}+\mu_{t} .
$$

When examining the stability of the components of the demand for money model, given the definition of money in use, the signs of coefficients are not constant. For example, as the interest rate on fixed deposits increases, the quantity demanded of deposits decreases, while fixed and savings deposits increase in volume. Surprisingly, Heller (1966, p.338) concluded that the components making up the total demand for money were stable. To test the stability of the demand for money function over time, Heller divided the sample into three sub-periods, with different definitions of money in each period. The sub-periods are Period I: 1918 to 1932; Period II: 1933 to 1946, and Period III: 1947 to 1955. It was found that only a money equation using a narrow definition of nominal balances was significant in the first period, regardless of the significant level. Heller concludes that the short- and long-run stability may differ and stated that "the demand for money function was stable only in the long run." However, this conclusion was misleading because, using a $t$-test, out of 29 parameters, less than half were significant. The simple regression model by Heller for the long-run showed the existence of instability in the parameters. For example, the money demand function for the period 1918-1955 was unstable, even though, according to Heller, this was the case for short-run only. Maxwell (1971) estimated a linear function using the same variables as Heller, in logarithmic form, for the period 1918-1960. Maxwell found that Heller did not estimate a stable long-run function for money because his model could not be fixed over both the pre- and post-war period. Maxwell (1971) developed a regression model with narrow and broadly defined real money stocks as the dependent variable and three 
explanatory variables. The variables were first, the interest rate (the rate of interest on 12-month fixed deposits) and GDP (current income), second, the interest rate and permanent income, and third, wealth and the interest rate for the whole period (1918-1960). "Over the whole period and both sub-periods, it was revealed that an interest elastic Permanent Income Model gave the best results, followed by a current model, and lastly the wealth model" (Maxwell, 1971, p.21). Furthermore, the interest rate's coefficient was a negative one, as expected from theory.

Looking at Maxwell's other results, 16 out of 18 values of the coefficient of determination $\left(\mathrm{R}^{2}\right)$ are all greater than 0.7 and nearly equal to one which indicates a supposed good fit. However, there were many extremely low Durbin-Watson statistics which indicates a possibility of misspecification in the analysis. In other words, the null hypothesis of no serial correlation (against the alternative) was rejected. However, Maxwell checked the possibility of misspecification by estimating the logarithm function of the demand for money by running two separate regressions (pre- and post-war periods) and the results were substantially different. Then he included a price variable to see if it could improve the regression. The results were not significantly different from the previous ones, although the price variable was significant. From this, Maxwell did not consider the low value of the DW as being caused by misspecification, but rather, it was as a result of using the linear function.

The linear function approach was also used by Stadler (1981, p.145-152) and, in his paper, all variables were in logarithmic form. When the log-linear model of the real money balances was analyzed, the determinants were real income and the interest rate. Also, both the broad and a narrow definition of money were used. For the interest rate, two types were used - a three-month bankers' acceptance rate and the rate on company stock debentures. Stadler used data for the period 1965: I to 1979: II. Stadler's estimated model shows that the coefficient of the interest rate is positive in all cases. He found the incorrect sign, as theory suggests, a negative relationship. Therefore, unlike Maxwell's result where the interest rate was found to be inelastic and based on the t- ratio, the interest elasticity is not statistically significant in a number of cases. This may be caused by the difference in time periods under study or also the different sample sizes. Stadler confirmed these results by running a regression of the narrow and broad money stock against a long-term interest rate. He showed a positive correlation between variables. This is in contrast to Contogiannis (1979), who discovered that the interest rate was significant when explaining movements in the velocity of narrow money. Although the coefficient of determination adjusted for degrees of freedom showed a good fit, like Maxwell's (1971) results, the Durbin-Watson statistics were very low, being close to zero, which leads to a rejection of the null hypothesis of no autocorrelation. Therefore there is an indication of a possible misspecification of the function. To elaborate on this, Stadler replaced the interest rate variable with the price level and the model specification became:

$$
M_{t}=\beta_{0}+\beta_{1} Y_{t}+\beta_{2} P_{t}+\mu_{t} .
$$

The results showed low price elasticity, meaning that price was not supposed to be one of the money demand function's determinants. To explain these results, Heller (1966, p.337) said, "this might be taken as an indicator of the presence of a certain type of money illusion on the part of the holders of money - as prices go up, they will not expand their money holdings because they believe that the nominal amount of money they do hold is able to perform its function, even with a higher price level. On the other hand, it might also reflect a conscious effort on behalf of the holders of money balances to economize on their use." Theoretically, money demand depends on the level of income and the interest rate, but in all studies using the linear function approach with the South African data, there is a failure to show a stable estimated specification for the long-run demand for money. To correct these short-comings, Contogiannis and Shahi (1982, p.26-34) suggested that a non-linear estimation technique should be used. They attempt this by using the partial lagged stock adjustment mechanism to model the long-run demand for money and we report these results in the previous section.

\section{THE BUFFER STOCK OR DISEQUILIBRIUM MONEY MODEL}

Milbourne (1987, p.130) wrote that "the buffer stock model has been a new growth industry in monetary economics and its success has been acclaimed or simply taken for granted, with little testing or discussing that normally accompanies a new theory". In South Africa, the buffer stock hypothesis has been employed in a number of empirical studies to show evidence of significant buffer-stock effects. Tavlas (1989, p.1-13) criticizes Whittaker, 
regarding Courakis' study, that the usage of the buffer stock model was an appropriate one in which money supply shocks were the appropriate determinants of real money balances. The disequilibrium money model is named from the assumption that the role of cash balances is to absorb unexpected inflows or outflows, acting as a buffer (Milbourne, 1987). It is believed that the buffer-stock model is supposed to be able to differentiate between shifts in money demand due to traditional factors, such as income and interest rates, and shifts due to expected changes in monetary policy. Tavlas sets out the conventional specification of the demand for real money balances as:

$m_{t}-p_{t}=a_{0}+a_{1} y_{t}+a_{2} r_{t}+a_{3}\left(m_{t-1}-p_{t-1}\right)+\mu_{t}$,

where $\mathrm{m}_{\mathrm{t}}, \mathrm{p}_{\mathrm{t}}$ and $\mathrm{y}_{\mathrm{t}}$ are the logarithm of a measure of the nominal money stock, price index and a scale variable such as income and wealth, respectively - while $r_{t}$ is the logarithm of an opportunity cost variable and $\mu_{t}$ is an error term. The lagged dependant variable of $\left(m_{t}-p_{t}\right)$ stands for adjustment costs. This model specification was used in previous studies and it is found that estimated coefficients using this form have been unstable, which is the reason why Tavlas proposed the following buffer stock model as an alternative to solve the problem:

$m_{t}-p_{t}=a_{0}+a_{1} y_{t}+a_{2} r_{t}+a_{3}\left(m_{t-1}-p_{t-1}\right)+a_{4}\left(m_{t}-m_{t}^{a}\right)+\mu_{t}$,

where $m_{t}^{a}=g^{1} z_{t}$ and $m_{t}=g^{1} z_{t}+v_{t}$ and $z_{\mathrm{t}}$ stands for the variables that have an important influence on the money supply, $m_{t}^{a}$ is the logarithm of the anticipated money supply, g represents a vector of coefficients to be estimated and $\mathrm{v}_{\mathrm{t}}$ is the white noise error term. To run these two models (28 and 29), South African data for the period 1977-1987 were used. The results from equation (28) show that real GDP, as a measure of income, was insignificant. The coefficient of the Treasury-Bill rate (used as the opportunity cost) was negative but insignificant, while the coefficient of the deposit rate was positive, as predicted by theory, but insignificant. The only significant variable was the lagged dependent variable. With the period split in half (1977: IV to 1983: III and 1983: IV to 1987: III), the Chow stability test was used to indicate that equation (28) is very unstable. Next Tavlas ran the regression eight times, with alternative variations of the explanatory variables, in order to find a regression that gave a more stable function. Inflationary expectations from equation (29) were tested and the results indicated that the coefficient had a negative sign and was statistically significant. Therefore, inflationary expectations did not have a separate impact on the demand for money, apart from their effect on nominal interest rates. In the same way, Tavlas replaced the Treasury-Bill rate by the long-term bond yield and there was some improvement; however, the Chow test continues to indicate instability.

Tavlas estimated a buffer stock model with a monetary shock term and the results showed that all parameters were statistically significant. The monetary shock variable was very significant and positive. The Chow statistic showed that the buffer stock model was stable. However, Tavlas discovered at least one problem with this type of model specification - the $\mathrm{m}_{\mathrm{t}}$ component of the unanticipated money supply variable may be correlated with the numerator of the dependent variable (real money balances). To address this problem, Tavlas used two procedures - first, replacing the money supply by the monetary base in order to generate a series of the anticipated monetary base. The motivation behind this replacement was that a change in the base influences changes in M3, which lessens the correlation between real money balances and a monetary shock term. Next, Tavlas replaced the unanticipated money base series by the unanticipated M3 series. After finding that the procedure used to derive the shock variable is not satisfactory, an alternative procedure was one of utilizing instrumental variables to generate an estimated series for $\mathrm{m}_{\mathrm{t}}$ and re-estimating equation (28). The empirical results were better because the monetary shock variable became highly significant and the Chow statistic showed some stability. Tavlas questioned that if the money supply is completely endogenous to the interest rate, the buffer stock model would not be an appropriate one for the South African economy because the disequilibrium money model relies on exogenous shocks to the money supply, influencing real money demand. Exogeneity is examined using Grangers' and Sims' tests. The results indicate that M3 Granger causes interest rates, but not the other way around. From all of the above, Tavlas concluded that there was a stable specification for M3 in South Africa. However, one may argue that ten years of quarterly data (a sample size of 40 observations) is not enough for a critical analysis of the demand for money, as it is easier to fit a stable function with smaller sample sizes. 


\section{CONCLUSION}

This paper and the review it presents showed that there are not many studies that used co-integration and Error Correction Model approaches on the demand for money using South African data. To be fair, many studies are from a period before the econometric literature developed these techniques; however, the observation of Shin (1994, p.91) - "the limiting distribution of test statistic for co-integration can be made free of nuisance parameters when the co-integration relation is efficiently estimated also shows that this test is consistent"- is instructive. To add to the literature on money demand estimates for South Africa, this paper proposes to use the above techniques as the prior literature offers "mixed-bag" of results. Overall, it appears the larger the time period studied, the less stable is the function. This seems rather obvious - there is more time for things to change.

\section{AUTHOR INFORMATION}

Ferdinand Niyimbanira is currently a Lecturer in Economics in the Faculty of Management Sciences at Vaal University of Technology (VUT), South Africa. He holds a Bachelor of Commerce Degree (Finance and Economics), Bachelor of Commerce Honours (Economics) and Master of Commerce (Economics), all obtained from University of KwaZulu Natal (UKZN). He is a PhD Candidate at North-West University (NWU), South Africa. He published many papers in national and international accredited academic journals. His current research interests are Macroeconomics, Financial Economics, Development Economics and economics of volunteers. E-mail: ferdinandn@vut.ac.za

\section{REFERENCES}

1. Baumol, W. J. (1952). The Transactions Demand for Cash: an Inventory Theoretical Approach. Quarterly Journal of Economics, 66, 545-556.

2. Boswijk, H. P. (1990). On the Scope of Conditional Dynamic Modelling of Cointegrated Variables. Tinbergen Institute Research Bulletin, 2(2), 97-108.

3. Charemza, W. W. and Deadman, D. F. (1993). New Direction in Econometric Practice: General to Specific Modelling, Co-integration and Vector Autoregression. Brookfield, Edward Elgar Publishing Limited.

4. Contogiannis, E. (1979, June). The Velocity of Money in South Africa. South Africa Journal of Economics, 47, 168-175.

5. Contogiannis, E. and Shahi, M. A. (1982). The Demand for Money and Inflationary Expectations in South Africa. South African Journal of Economics, 52(1), 1-41.

6. Cooley, T. F. and LeRoy, S. F. (1981, December). Identification and Estimation of Money Demand. American Economic Review, 71, 825-844.

7. Courakis, A. S. (1984).The Demand for Money in South Africa: Towards a More Accurate Perspective. South African Journal of Economics, 1(52), 1-41.

8. Cuthbertson, K. and Taylor, P. M. (1987). Buffer-Stock Money: An Appraisal. In the Operation and Regulation of Financial Markets, ed. by Goodhart, C. A.E, Currie, D. A and Llewellyn, D. T. London; The Macmillan Press Ltd.

9. De Kock, G. (1956). Prof. Lanchmann and Velocity of Circulation- A Rejoinder. South Africa Journal of Economics, 24, 25-28.

10. Engle, R. F. and Granger, C.W.J. (1987). Co-integration and Error Corrections: Representation, Estimation and Testing. Econometrica, 55(2), 251-276.

11. Friedman, M. (1956). The Quantity Theory of Money: A Restatement. Studies in the Quantity of Money. In Readings in Macroeconomics by Mueller, M.G. Reprinted from Chicago, University of Chicago Press, 321.

12. Friedman, M. (1957). A Theory of the Consumption Function. Princeton University Press.

13. Friedman, M. (1959). The Demand for Money: Some Theoretical and Empirical Results. Journal of Political Economy 67, 327-351.

14. Goodfriend, M. (1985). Reinterpreting Money Demand Regressions. Carnegie-Rochester Conference Series on Public Policy, 22, 207-242.

15. Granger, C. W. J. (1986). Developments in the Study of Cointegrated Economic Variables. Oxford Bulletin of Economics and Statistics, 48, 213-228. 
16. Handa, J. (2000). Monetary Economics. New York, Routledge.

17. Heller, H. R. (1966). The Demand for Money in South Africa. The South African Journal of Economics, 34, 335-340.

18. Hendry, D. F. (1985). Monetary Economic Myth and Econometric Reality. Oxford Review of Economic Policy, 1, 72-84.

19. Hendry, D. F. and Mizon, G. (1978). Serial Correlation as a Convenient Simplification, not a Nuisance: A comment on a Study of the Demand by the Bank of England. The Economic Journal, 88, 549-563.

20. Hurn, A. S. and Muscatelli, V. A. (1992). The Long-run Properties of Demand for M3 in South Africa. South African Journal of Economics, 60(2), 158-172.

21. Inder, B. (1993). Estimating Long-Run Relationship in Economics: A Comparison of Different Approaches. Journal of Econometrics, 57(1), 53-68.

22. Kennedy, P. (1998). A Guide to Econometrics. $4^{\text {th }}$ Edition. Massachusetts, Blackwell Publishers Inc.

23. Lachmann, L. M. (1956). The Velocity of Circulation as a Predictor. South African Journal of Economics, 24, 17-24.

24. Maxwell, T. (1971). The Long-Run Demand for Money in South Africa (1918-19600: Some Preliminary Findings. South African Journal of Economics, 39, 13-30.

25. Milbourne, R. (1987). Re-Examining the Buffer-Stock Model of Money. The Economic Journal, 97, 130142 .

26. Milbourne, R. (1988). Disequilibrium Buffer Stock Models: A Survey. Journal of Economic Surveys, 2(3), 187-208.

27. Moll, P. G. (2000). The Demand for Money in South Africa: Parameter Stability and Predictive Capacity. The South African Journal of Economics, 68(2), 190-208.

28. Naudè, W. A. (1992). Do the Error Correction Models Contribute Towards Understanding Money Demand in South Africa. Journal for Studies in Economics and Econometrics, 16(3), 51-62.

29. Nell, K. S. (2003). The Stability of M3 Money Demand and Monetary Growth Targets: The Case of South Africa. Journal of Development Studies, 39(3), 233-252.

30. Shin, Y. (1994). A Residual-Based Test of the Null of Co-integration against the Alternative of No Cointegration. Economic Theory, 10, 91-115.

31. Sriram, S. (2001). A Survey of Recent Empirical Money Demand Studies. IMF Staff Papers, 47(3), 334364.

32. Stadler, G. (1981). The Demand for Money in South Africa. South African Journal of Economics, 49(2), 145-152.

33. Tavlas, G. S. (1989). The Demand for Money in South Africa: a Test of the Buffer Stock Model. South African Journal of Economics, 57(1), 1-13.

34. Tlelima, T. and Turner, P. (2004). The Demand for Money in South Africa: Specification and Tests for Instability. South African Journal of Economics, 72(2), 25-36.

35. Whittaker, J. (1985). The Demand for Money in South Africa: Towards a More Accurate Perspective. South African Journal of Economics, 53(2), 184-196. 